\title{
Pengaruh Perputaran Kas dan Perputaran Piutang Terhadap Profitabilitas
}

\author{
Heikal Muhammad Zakaria Hakim¹, Gusganda Suria Manda², Arif Rakhman ${ }^{3}$ \\ Universitas Singaperbangsa Karawang \\ heikalzakaria@gmail.com
}

\begin{abstract}
This study aims to determine the effect of cash turnover and accounts receivable turnover on profitability (ROA) in cosmetics and household needs companies listed on the Indonesia Stock Exchange in the period 2011-2016. The independent variables in this study are cash turnover and accounts receivable turnover. For the dependent variable in this study is profitability (ROA). The population taken in this study were cosmetics and household needs companies listed on the Indonesia Stock Exchange during the period of 2011 - 2016. The sampling technique used was purposive sampling technique and obtained a sample of 5 companies. the type of data used is secondary data taken by the method of documentation and literature study. The data analysis technique used is multiple linear regression analysis, classic assumption test and hypothesis test using $t$ test. The results of the partial hypothesis test show that there is a significant positive effect between cash turnover on profitability (ROA) and there is a significant positive effect between accounts receivable turnover to profitability $(\mathrm{ROA})$.
\end{abstract}

\begin{abstract}
Abstrak- Penelitian ini bertujuan untuk mengetahui pengaruh perputaran kas dan perputaran piutang terhadap profitabilitas (ROA) pada perusahaan kosmetik dan keperluan rumah tangga yang terdaftar di Bursa Efek Indonesia periode 2011 - 2016. Variabel independen dalam penelitian ini adalah perputaran kas dan perputaran piutang. Untuk variabel dependen dalam penelitian ini adalah profitabilitas (ROA). Populasi yang diambil dalam penelitian ini adalah perusahaan kosmetik dan keperluan rumah tangga yang terdaftar di Bursa Efek Indonesia selama periode 2011 - 2016. Teknik pengambilan sampel yang digunakan adalah teknik purposive sampling sejumlah 5 perusahaan. jenis data yang digunakan adalah data sekunder yang diambil dengan metode dokumentasi dengan cara mengakses beberapa situs dan studi pustaka. Teknik analisis data yang digunakan adalah analisis regresi linier berganda, uji asumsi klasik dan uji hipotesis menggunakan uji t. Hasil penelitian uji hipotesis secara parsial menunjukkan bahwa terdapat pengaruh positif yang signifikan antara perputaran kas terhadap profitabilitas (ROA) dan terdapat pengaruh positif yang signifikan antara perputaran piutang terhadap profitabilitas (ROA).
\end{abstract}

Kata Kunci- Perputaran Kas, Perputaran Piutang, Profitabilitas (ROA)

\section{PENDAHULUAN}

Dalam memasuki perkembangan dunia ekonomi yang semakin luas, terlihat dari adanya perkembangan serta persaingan yang ketat dalam dunia usaha, baik perdagangan, jasa, maupun perindustrian, serta adanya peningkatan tuntutan konsumen akan produk atau barang dan jasa yang dikonsumsi. Maka, setiap perusahaan yang tumbuh dan berkembang diwajibkan untuk mempunyai daya saing yang kuat agar dapat mencapai tujuan dari perusahaan yaitu untuk menghasilkan laba yang optimal agar dapat mempertahankan kelangsungan operasional perusahaan, memajukan, serta mengembangkan usahanya ke tingkat yang lebih tinggi atau ke tingkat yang lebih baik.

Pada umumnya modal kerja terdiri dari beberapa elemen yang terdiri dari seluruh aktiva lancar yang akan selalu berputar dalam kegiatan perusahaan. Menurut Riyanto (2013: 94) bahwa kas adalah salah satu unsur modal kerja yang paling tinggi tingkat likuiditasnya. Makin besar jumlah kas yang ada di dalam perusahaan berarti makin tinggi tingkat likuiditasnya. Ini berarti bahwa perusahaan mempunyai risiko yang lebih kecil untuk tidak dapat memenuhi kewajiban finansiilnya. Tetapi ini tidak berarti bahwa perusahaan harus berusaha untuk mempertahankan persediaan kas yang sangat besar, karena makin besarnya kas berarti makin banyaknya uang yang menganggur sehingga akan memperkecil profitabilitasnya. Sebaliknya kalau perusahaan hanya mengejar profitability saja, perusahaan akan berusaha agar semua persediaan kasnya dapat diputarkan atau dalam keadaan bekerja. Jika perusahaan menjalankan tindakan tersebut berarti menempatkan perusahaan itu dalam keadaan illikuid apabila sewaktu - waktu ada tagihan. Maka, menurut Riyanto (2013: 95) bahwa semakin tinggi perputaran kas akan semakin baik, karena ini berarti semakin tinggi efisiensi penggunaan kasnya.

Selain daripada kas, komponen lainnya adalah piutang. Menurut Nurkayati (2014: 2) bahwa dalam kegiatan penjualan barang dapat dilakukan secara tunai ataupun kredit. Dalam lingkup perusahaan kecil, biasanya kegiatan penjualan dilakukan secara tunai, dengan demikian hasil penjualan pada hari itu dapat langsung diketahui, yaitu dari besarnya uang yang diterima. Sistem penjualan seperti ini dapat membatasi omzet penjualan karena calon pembeli yang tidak mempunyai uang cukup, tidak bisa membeli barang barang yang dibutuhkan, dan hanya terbatas pada calon 
pembeli yang mempunyai uang tunai. Sistem penjualan ini bahkan dapat menurunkan omzet penjualan karena calon pembeli yang tidak mempunyai uang akan mencari penjual yang menjual barangnya secara kredit. Upaya meningkatkan omzet penjualan dan memenuhi sebagian besar pelanggan maka dilakukan kebijakan penjualan secara kredit. Kebijakan penjualan kredit biasanya akan menjadi pilihan bagi pelanggan dalam hubungannya dengan pengelolaan dana yang diperlukan. Dengan sistem penjualan kredit, diharapkan dapat menaikkan omzet penjualan, yang berarti juga akan berpengaruh terhadap posisi keuangan perusahaan. Akan tetapi, dengan semakin besarnya piutang yang dimiliki perusahaan, akan menimbulkan risiko, yaitu tidak tertagihnya piutang, sehingga akan menjadi beban kerugian perusahaan. Oleh karena itu, perlu adanya pengelolaan dalam piutang.

Menurut Riyanto (2013: 85) bahwa perputaran piutang (receivable turnover) menunjukkan periode terikatnya modal kerja dalam piutang dimana semakin cepat periode berputarnya menunjukkan semakin cepat perusahaan mendapatkan keuntungan dari penjualan kredit tersebut, sehingga profitabilitas perusahaan juga ikut meningkat. Semakin tinggi tingkat perputaran piutang suatu perusahaan, semakin baik pengelolaan piutangnya menandakan pengembalian laba yang baik.

Dalam penelitian ini, objek yang akan diteliti adalah seluruh perusahaan kosmetik dan keperluan rumah tangga yang terdaftar di BEI periode 2011 2016. Industri kosmetik dan keperluan rumah tangga menjadi salah satu industri yang memiliki perkembangan pesat dari tahun ke tahun. Bahkan industri ini mengantongi predikat sebagai penyumbang nilai ekspor tinggi bagi Negara. Meski terkesan kurang terekspos media, tapi nyatanya industri kosmetik dan keperluan rumah tangga terus memberikan perkembangan yang signifikan dibanding industri lainnya (www.manufakturindo.com, situs berita industri 2018).

Terdapat fenomena pada industri-industri yang bergerak dibidang kosmetik dan keperluan rumah tanggan yaitu penulis membandingkan tingkat ROA pada 5 perusahaan kosmetik dan keperluan rumah tangga selama tahun 2011 - 2016. ROA pada PT. Mustika Ratu Tbk dan PT. Akasha Wira International Tbk mengalami fluktuasi dari tahun 2011 - 2016. Kemudian PT. Martina Berto Tbk, PT. Mandom Indonesia Tbk dan PT. Unilever Indonesia Tbk mengalami penurunan tingkat ROA dari tahun 2011 2014.
Ada kalanya saat perputaran kas dan perputaran piutang meningkat, laba yang diperoleh perusahaan justru lebih kecil dari tahun sebelumnya. Dan perusahaan dengan tingkat perputaran kas dan perputaran piutang yang tinggi belum tentu menghasilkan Return On Assets (ROA) yang tinggi. Berdasarkan fenomena tersebut perputaran kas dan perputaran piutang bukanlah satu - satunya faktor yang dipertimbangkan pihak manajemen dalam menetapkan besarnya laba yang diperoleh. Ada banyak faktor yang mempengaruhi Return On Assets (ROA) perusahaan seperti perputaran aktiva tetap, faktor pengawasan, ketentuan dari pemerintah dan faktor lainnya.

Menurut Riyanto (2013: 36) bahwa profitabilitas merupakan perbandingan antara laba usaha dengan modal sendiri dan modal asing yang dipergunakan untuk menghasilkan laba tersebut dan dinyatakan dalam persentase. Oleh karena itu, pengertian profitabilitas sering dipergunakan untuk mengukur efisiensi penggunaan modal di dalam suatu perusahaan, maka profitabilitas sering pula dimaksudkan sebagai kemampuan suatu perusahaan dengan seluruh modal yang bekerja di dalamnya untuk menghasilkan laba.

Rasio profitabilitas dalam penelitian ini menggunakan rasio Return on Assets (ROA). Menurut penelitian yang dilakukan oleh Venti Linda Verawati dan Hening Widi Oetomo (2014) bahwa ROA merupakan salah satu rasio profitabilitas yang menunjukkan seberapa banyak laba bersih yang bisa diperoleh dari seluruh kekayaan yang dimiliki perusahaan. Rasio ini mengukur efektifitas perusahaan di dalam menghasilkan keuntungan dengan memanfaatkan aktiva yang dimilikinya. Rasio ini merupakan rasio terpenting di antara profitabilitas lainnya. ROA merupakan rasio keuangan yang dominan mempengaruhi return saham karena merupakan ROA earning power keuangan perusahaan. Dan semakin besar ROA menunjukkan kinerja yang semakin baik, karena tingkat pengembalian semakin besar. Kebanyakan perusahaan yang memiliki pusat investasi mengevaluasi unit usahanya dengan dasar ROA, hal ini dikarenakan ada 3 keuntungan dari ROA, pertama ROA mendorong manager untuk memperhatikan pada hubungan antara penjualan, cost dan investasi. Kedua, ROA mendorong manager untuk menghemat cost atau fokus pada efisiensi biaya, ketiga ROA mencegah investasi yang dipandang berlebihan. Selain itu, data ROA dapat diketahui oleh pesaing dan dapat dijadikan dasar perbandingan kinerja keuangan.

Penelitian - penelitian mengenai perputaran kas diantaranya yang dilakukan oleh L. Rizkiyanti 
Putri dan Lucy Sri Musmini (2013) dan Yuliyati dan Sunarto (2014) mengatakan bahwa perputaran kas berpengaruh signifikan positif terhadap profitabilitas. Terdapat hasil yang berbeda pada penelitian yang dilakukan oleh Ni Kadek Dewi Asih, I Made Adi Pradana Adiputra, dan Nyoman Ari Surya Darmawan (2014) mengatakan bahwa tingkat perputaran kas berpengaruh negatif dan tidak signifikan terhadap profitabilitas.

Selanjutnya penelitian - penelitian mengenai perputaran piutang diantaranya yang dilakukan oleh Venti Linda Verawati dan Hening Widi Oetomo (2014) dan Diah Ayu Purnamasari dan Astri Fitria (2015) mengatakan bahwa perputaran piutang berpengaruh signifikan positif terhadap profitabilitas. Hasil yang berbeda pada penelitian Luh Komang Suarnami, I Wayan Suwendra, dan Wayan Cipta (2014) mengatakan bahwa perputaran piutang tidak berpengaruh signifikan terhadap profitabilitas.

\section{KAJIAN PUSTAKA}

Perputaran Kas (Cash Turnover)

Menurut Riyanto (2013: 94) bahwa kas adalah salah satu unsur modal kerja yang paling tinggi tingkat likuiditasnya. Makin besar jumlah kas yang ada di dalam perusahaan berarti makin tinggi tingkat likuiditasnya. Ini berarti bahwa perusahaan mempunyai risiko yang lebih kecil untuk tidak dapat memenuhi kewajiban finansiilnya. Tetapi ini tidak berarti bahwa perusahaan harus berusaha untuk mempertahankan persediaan kas yang sangat besar, karena makin besarnya kas berarti makin banyaknya uang yang menganggur sehingga akan memperkecil profitabilitasnya. Sebaliknya kalau perusahaan hanya mengejar profitability saja akan berusaha agar semua persediaan kasnya dapat diputarkan atau dalam keadaan bekerja. Kalau perusahaan menjalankan tindakan tersebut berarti menempatkan perusahaan itu dalam keadaan illikuid apabila sewaktu - waktu ada tagihan.

Menurut Riyanto (2013: 95) bahwa perputaran kas adalah perbandingan antara penjualan bersih dengan jumlah rata - rata kas yang menggambarkan tingkat perputaran kas (cash turnover). Semakin tinggi perputaran kas akan semakin baik, karena ini berarti semakin tinggi efisiensi penggunaan kasnya.

Perputaran Piutang (Receivable Turnover)

Menurut Hery (2016: 179) bahwa perputaran piutang usaha merupakan rasio yang digunakan untuk mengukur berapa kali dana yang tertanam dalam piutang usaha akan berputar dalam satu periode atau berapa lama (dalam hari) rata - rata penagihan piutang usaha. Rasio ini menunjukkan kualitas piutang usaha dan kemampuan manajemen dalam melakukan aktivitas penagihan piutang usaha tersebut. Dengan kata lain, rasio ini menggambarkan seberapa cepat piutang usaha berhasil ditagih menjadi kas.

Menurut Riyanto (2013: 85) bahwa perputaran piutang (receivable turnover) menunjukkan periode terikatnya modal kerja dalam piutang dimana semakin cepat periode berputarnya menunjukkan semakin cepat perusahaan mendapatkan keuntungan dari penjualan kredit tersebut, sehingga profitabilitas perusahaan juga ikut meningkat. Semakin tinggi tingkat perputaran piutang suatu perusahaan, semakin baik pengelolaan piutangnya menandakan pengembalian laba yang baik. Profitabilitas

Profitabilitas dinilai sangat penting, karena untuk melangsungkan hidup suatu perusahaan haruslah berada dalam keadaan menguntungkan atau profitable. Tanpa keuntungan maka sulit bagi perusahaan untuk menarik modal dari luar. Hasil pengembalian investasi atau lebih dikenal dengan nama return on investment atau return on total assets, merupakan rasio yang menunjukkan hasil (return) atas jumlah aktiva yang digunakan dalam perusahaan. ROI atau ROA juga merupakan suatu ukuran tentang efektifitas manajemen dalam mengelola investasinya

\section{METODE PENELITIAN}

Dalam penelitian ini, maka yang menjadi populasi penelitian adalah seluruh perusahaan kosmetik dan keperluan rumah tangga yang terdaftar di Bursa Efek Indonesia dengan jumlah 6 perusahaan.

Pengambilan sampel dalam penelitian ini dilakukan dengan menggunakan teknik purposive sampling. Menurut Sujarweni (2016: 7) bahwa purposive sampling adalah teknik penentuan sampel dengan pertimbangan atau kriteria - kriteria tertentu.

Jenis data yang dikemukakan melalui penelitian ini menggunakan jenis data sekunder. Data sekunder merupakan data yang diperoleh tidak secara langsung dari objek penelitian. Peneliti mendapatkan data yang sudah jadi yang diolah dan dikumpulkan oleh pihak lain dengan berbagai cara atau metode baik secara komersial maupun non komersial serta sudah dalam bentuk publikasi. Sumber data dalam penelitian ini menggunakan data sekunder berupa laporan keuangan pada perusahaan fsh yang terdaftar di Bursa Efek Indonesia (BEI) periode 2011 - 2016. Sumbernya yaitu dengan cara mengunduh laporan keuangan tersebut dari website www.idx.co.id. 
Teknik pengumpulan data yang digunakan dalam penelitian ini adalah studi kepustakaan dan dokumentasi

Setelah data yang dibutuhkan dalam penyusunan terkumpul, maka langkah selanjutnya adalah menganalisa data. Metode analisis data yang digunakan dalam penelitian ini adalah metode analisis regresi linier berganda. Metode tersebut digunakan untuk meramalkan pengaruh dari suatu variabel terikat (profitabilitas perusahaan) berdasarkan variabel bebas (perputaran kas dan perputaran piutang). Data yang diperoleh kemudian dianalisis dengan analisis regresi berganda, dengan menggunakan program SPSS versi 23. Uji normalitas merupakan syarat dalam penelitian kuantitatif sebagai bukti empiris. Bisa diuji menggunakan uji Normal Kolmogorov - Smirnov.

Selanjutnya perlu dilakukan uji multikolinieritas untuk menguji apakah ada multikolinieritas. multikolinieritas adalah adanya lebih dari satu hubungan linier yang sempurna. Jika VIF yang dihasilkan diantara 1-10 maka tidak terjadi multikolinieritas.

Setelah terbukti tidak terjadi Multikolinieritas maka selanjutnya dilakukan uji autokorelasi sering dikenal dengan istilah korelasi serial dan sering ditemukan pada data serial waktu (time series). Mendeteksi autokorelasi dengan menggunakan nilai Durbin Watson dibandingkan dengan tabel Durbin Watson (dl dan du). Kriteria jika du $<$ d hitung $<4$-du maka tidak terjadi autokorelasi. Selanjutnya harus dilakukan uji heteroskedastisitas. Cara memprediksi ada tidaknya heteroskedastisitas pada suatu model dapat dilihat dengan pola gambar Scatterplot.

\section{HASIL DAN PEMBAHASAN}

Uji normalitas ini bertujuan untuk mengetahui distribusi data dalam variabel yang akan digunakan dalam penelitian. Data yang baik dan layak digunakan dalam penelitian adalah data yang memiliki distribusi normal.

Untuk mendeteksi ada tidaknya gejala multikolinieritas antar variabel independen digunakan Variance Inflation Factor (VIF) dan Tolerance.. Berdasarkan hasil output SPSS versi 23 maka besar nilai VIF dan tolerance dapat dilihat pada tabel 1 , sebagai berikut :

Tabel 1 Uji multikolineritas

\begin{tabular}{cc}
\hline \multicolumn{2}{c}{ Collinearity Statistics } \\
\hline Tolerance & VIF \\
\hline 0,393 & 2,546 \\
\hline 0,393 & 2,546 \\
\hline
\end{tabular}

Menunjukkan bahwa kedua variabel independen yakni perputaran kas dan perputaran piutang memiliki nilai tolerance $>0,10$ dan VIF $<10$. Dengan demikian dapat disimpulkan bahwa model regresi tersebut tidak terjadi multikolinieritas.

Uji autokorelasi bertujuan untuk menguji apakah dalam suatu model regresi ada korelasi antara kesalahan pengganggu pada periode $t$ dengan kesalahan pada periode $\mathrm{t}-1$. Untuk dapat mengetahui adanya autokorelasi pada sampel penelitian maka di gunakan metode Durbin-Watson (DW).

Berdasarkan hasil uji autokorelasi menunjukkan bahwa hasil uji autokorelasi menunjukkan nilai Durbin-Watson sebesar 2,009. Dengan k sebesar 3 dan n sebanyak 30 maka nilai dl sebesar 1.2837 dan du sebesar 1.5666. Sehingga nilai ini terletak pada $\mathrm{dl}<\mathrm{d}<4-$ du yakni $1,2837<2,009$ $<2,4334$ (tidak ditolak).

Heteroskedastisitas menguji terjadinya perbedaan variance residual suatu periode pengamatan ke periode pengamatan yang lain. Cara memprediksi ada tidaknya heteroskedastisitas pada suatu model dapat dilihat dengan pola gambar Scatterplot

Dalam penelitian ini uji heteroskedastisitas dilakukan dengan analisa gambar plot antara nilai prediksi variabel terikat (ZPRED) dengan residualnya (SRESID) yang ditunjukkan pada gambar 1 sebagai berikut :

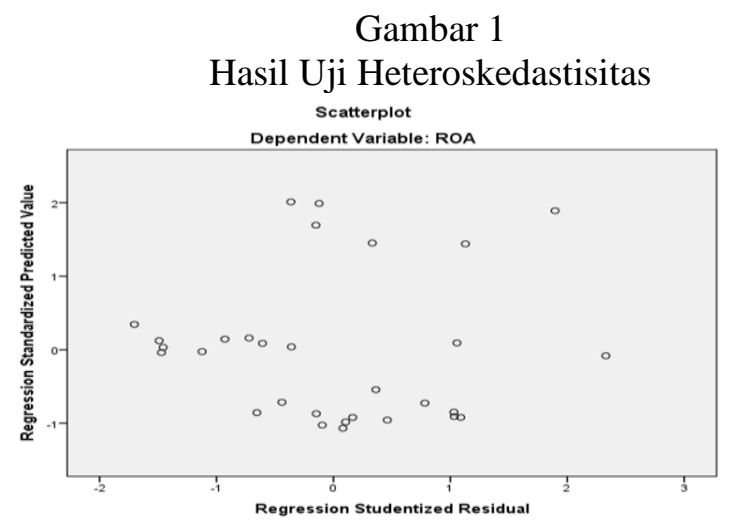

Sumber : Data diolah melalui SPSS versi 23, 2018.

Berdasarkan hasil uji heteroskedastisitas pada gambar 1 di atas dapat dilihat bahwa titik - titik yang ada tidak membentuk pola yang teratur. 
Uji t digunakan untuk menguji apakah suatu variabel bebas berpengaruh atau tidak terhadap variabel terikat. Pengujian secara parsial ini bertujuan untuk melihat seberapa jauh pengaruh satu variabel bebas secara individual dalam menerangkan variasi variabel terikat.

Pada penelitian ini, hasil pengujian hipotesis secara parsial (uji t) dapat dilihat pada tabel 2, sebagai berikut :

\begin{tabular}{llcc}
\hline Model & T & Sig. \\
& & & \\
\hline 1 & (Constant) & $-3,736$ & 0,001 \\
\cline { 2 - 3 } & Perputaran Kas & 2,573 & 0,016 \\
\cline { 2 - 3 } & Perputaran Piutang & 6,282 & 0,000
\end{tabular}

Tabel 2 Uji Hipotesis Secara Parsial

Berdasarkan hasil uji t pada tabel 2 diatas dapat dilihat nilai $\mathrm{t}$ statistik variabel perputaran kas sebesar 0,016 yang berarti $<0,05$ yang artinya terdapat pengaruh yang signifikan dari variabel bebas terhadap variabel terikat. Nilai t statistik pada variabel perputaran piutang sebesar 0,000 yang berarti $<0,05$ yang artinya terdapat pengaruh yang signifikan dari variabel bebas terhadap variabel terikat.

Hal ini menjelaskan bahwa jumlah kas dapat pula dihubungkan dengan jumlah penjualan (sales). Perbandingan antara penjualan dengan jumlah kas rata - rata menggambarkan tingkat perputaran kas (cash turnover). Menurut Riyanto (2013: 95) bahwa perputaran kas adalah perbandingan antara penjualan dengan jumlah kas rata - rata. Semakin tinggi tingkat perputaran kas berarti semakin cepat kembalinya kas masuk pada perusahaan. Dengan demikian kas akan dapat dipergunakan kembali untuk membiayai kegiatan operasional sehingga tidak mengganggu kondisi keuangan perusahaan. Dimana rata - rata kas dan bank dapat dihitung dari saldo kas dan bank awal ditambah saldo kas dan bank akhir dibagi dua. Makin tinggi perputaran kas berarti makin tinggi efisiensi penggunaan kasnya.

Hasil penelitian ini didukung oleh penelitian sebelumnya yang dilakukan oleh L. Rizkiyanti Putri dan Lucy Sri Musmini (2013) serta Yuliyati dan Sunarto (2014) dalam

Berdasarkan hasil uji t pada tabel 2 diketahui bahwa variabel perputaran piutang menunjukkan nilai $\mathrm{t}$ hitung sebesar 9,838 dengan profitabilitas signifikansi sebesar 0,000 dimana tingkat signifikansi tersebut lebih kecil dari taraf signifikansi $\alpha=0,05$. Hal ini menunjukkan bahwa terdapat pengaruh positif yang signifikan antara perputaran piutang terhadap profitabilitas $(R O A)$.

Hal ini menjelaskan bahwa perputaran piutang yang tinggi mencerminkan kemampuan perusahaan dalam mengelola piutangnya dengan baik. Piutang yang dikelola dengan baik akan menyebabkan risiko piutang tak tertagih menjadi kecil dan kemampuan perusahaan dalam meminimalisir kredit macet sehingga perputaran piutang tidak terganggu dan perusahaan dapat meningkatkan profitabilitas dengan seiring lancarnya jumlah penjualan.

Sesuai dengan pendapat yang di sampaikan oleh Hery (2016: 179) bahwa perputaran piutang usaha merupakan rasio yang digunakan untuk mengukur berapa kali dana yang tertanam dalam piutang usaha akan berputar dalam satu periode atau berapa lama (dalam hari) rata - rata penagihan piutang usaha. Rasio ini menunjukkan kualitas piutang usaha dan kemampuan manajemen dalam melakukan aktivitas penagihan piutang usaha tersebut. Dengan kata lain, rasio ini menggambarkan seberapa cepat piutang usaha berhasil ditagih menjadi kas.

Tingginya perputaran piutang juga mencerminkan longgarnya kebijakan kredit yang dimiliki perusahaan. Kebijakan kredit yang longgar mengindikasikan tersedianya kas, persediaan, dan sekuritas dalam jumlah yang cukup besar pada perusahaan - perusahaan sampel. Sehingga perusahaan tersebut cenderung tidak bergantung pada penjualan secara kredit. Dengan demikian, perusahaan dapat memaksimalkan profitnya melalui penjualan secara tunai.

Hasil penelitian ini didukung oleh penelitian sebelumnya yang dilakukan oleh Venti Linda Verawati dan Hening Widi Oetomo (2014) serta Diah Ayu Purnamasari dan Astri Fitria (2015) yang keduanya menunjukkan bahwa adanya pengaruh perputaran piutang terhadap profitabilitas

\section{KESIMPULAN DAN SARAN}

Kesimpulan

Perputaran kas yang berpengaruh terhadap profitabilitas $(R O A)$ disebabkan oleh jumlah penjualan yang tinggi dengan rata - rata kas yang rendah sehingga profitabilitas perusahaan meningkat.

Adanya para investor yang menambah investasi bagi perusahaan dalam pendanaan operasionalnya sehingga, perputaran kas mampu mengalami peningkatan, pihak - pihak perusahaan yang mengelola kas dengan efektif sehingga akan berdampak perputaran kas menjadi tinggi dan adanya 
hubungan yang baik antara perusahaan dan konsumen untuk memudahkan setiap jenis transaksi sehingga perputaran kas menjadi tinggi. Perputaran piutang yang berpengaruh terhadap profitabilitas (ROA) disebabkan oleh kemampuan perusahaan dalam mengelola piutangnya dengan baik.

Piutang yang dikelola dengan baik akan menyebabkan risiko piutang tak tertagih menjadi kecil dan kemampuan perusahaan dalam meminimalisir kredit macet sehingga perputaran piutang tidak terganggu dan perusahaan dapat meningkatkan profitabilitas dengan seiring lancarnya jumlah penjualan. Adanya pihak - pihak perusahaan yang mengelola piutang dengan efektif dan juga mengkaji kembali kebijakan kreditnya sesuai dengan situasi dan kondisi suatu perusahaan sehingga akan berdampak perputaran piutang menjadi tinggi, syarat waktu pembayaran kredit perusahaan yang pendek dan hubungan yang baik antara perusahaan dengan konsumen untuk memudahkan transaksi kredit sehingga perputaran piutang menjadi tinggi.

\section{Saran}

Berdasarkan hasil penelitian diatas, peneliti memberikan saran yang diharapkan mampu menjadi penambah informasi bagi pihak yang berkepentingan yaitu dapat menggunakan seluruh variabel dalam penelitian ini sebagai pertimbangan perusahaan untuk dapat meningkatkan kemampuan perusahaan dalam menghasilkan profitabilitas perusahaan.

Perusahaan sebaiknya memperhatikan pengelolaan kas dan piutang dengan memperhatikan perputaran kas dan perputaran piutangnya agar lebih efektif dan efisien, sehingga bisa mencapai profitabilitas yang tinggi.

Peneliti selanjutnya dapat menggunakan variabel bebas yang berbeda dan belum digunakan dalam penelitian ini atau menambah variabel bebas baru yang dapat memberikan kontribusi terhadap profitabilitas.

\section{REFERENSI}

[1] Asih, N.K.D., dkk. 2014. "Pengaruh Tingkat Perputaran Kas, Tingkat Pertumbuhan Jumlah Nasabah dan Ukuran Perusahaan pada Profitabilitas Koperasi Simpan Pinjam (KSP) di Kecamatan Buleleng”. Volume. 2, Nomor. 1, 2014. Singaraja: Universitas Pendidikan Ganesha.

[2] Bursa Efek Indonesia. 2018. "Laporan Keuangan dan Tahunan”. www.idx.co.id. (diakses : 02 April 2018)
[3] Hery. 2009. “Akuntansi Keuangan Menengah I". Jakarta: PT. Bumi Angkasa.

[4] Hery. 2015. "Analisis Kinerja Manajemen". Jakarta: Gramedia Widiasarana. (diakses : 10 April 2018)

[5] Hery. 2016. "Analisis Laporan Keuangan Integrated and Comprehensive Edition". Jakarta: PT. Grasindo. (diakses : 10 April 2018)

[6] Kasmir. 2009. "Pengantar Manajemen Keuangan : Edisi Kedua”. Jakarta: Kencana Prenada Media Group. (diakses : 10 April 2018)

[7] Kasmir. 2011. “Analisis Laporan Keuangan”. Jakarta: PT. Rajagrafindo Persada. (diakses : 10 April 2018)

[8] Manufakturindo. 2018. "Apa Kabar Industri Kosmetik Indonesia?". www.manufakturindo.com. (diakses : 02 April 2018)

[9] Narayana, I.P.G. 2013. "Pengaruh Perputaran Kas, Loan To Deposit Ratio, Tingkat Permodalan dan Leverage Terhadap Profitabilitas Bank Perkreditan Rakyat (BPR) Se-kota Denpasar Periode 2009-2011”. Bali: Universitas Udayana.

[10] Nurkayati. 2014. "Mengelola Kartu Piutang dan Utang”. Bogor: CV Bina Pustaka.

[11] Purnamasari, D.A. dan Astri F. 2015. "Pengaruh Perputaran Piutang dan Ukuran Perusahaan Terhadap Profitabilitas Perusahaan Kimia”. Volume. 4, Nomor. 8, 2015. Surabaya: Sekolah Tinggi Ilmu Ekonomi Indonesia.

[12] Putri, L.R., dan Lucy S.M. 2013. "Pengaruh Perputaran Kas Terhadap Profitabilitas pada PT. Tirta Mumbul Jaya Abadi Singaraja Periode 2008-2012". Volume. 3, Nomor. 2, 2013. Singaraja: Universitas Pendidikan Ganesha.

[13] Ray, S. 2012. "Evaluating the Impact of Working Capital Management Components on Corporate Profitability : Evidence from Indian Manufacturing Firm's". Volume. 2, Nomor. 3, 2012. India: University Of Calcutta.

[14] Riyanto, B. 2013. "Dasar - Dasar Pembelanjaan Perusahaan Edisi 4". Yogyakarta: BPFE-Yogyakarta.

[15] Saham OK. 2018. "Daftar Perusahaan Publik". www.sahamok.com. (diakses : 02 April 2018)

[16] Suarnami, L.K, dkk. 2014. "Pengaruh Perputaran Piutang dan Periode Pengumpulan Piutang Terhadap Profitabilitas pada 
Perusahaan Pembiayaan”. Volume. 2, 2014. Singaraja: Universitas Pendidikan Ganesha.

[17] Sujarweni, V.W. 2016. "Kupas Tuntas Penelitian Akuntansi dengan SPSS". Yogyakarta: Pustaka Baru Press.

[18] Verawati, V.L dan Hening W.O. 2014. "Pengaruh Perputaran Modal Kerja, Perputaran Piutang, dan Perputaran Persediaan Terhadap Profitabilitas Perusahaan Tekstil". Volume. 3, Nomor. 9, 2014. Surabaya: Sekolah Tinggi Ilmu Ekonomi Indonesia.
[19] Yuliyati dan Sunarto. 2014. "Pengaruh Perputaran Modal Kerja, Perputaran Kas, dan Struktur Modal Terhadap Profitabilitas Perusahaan Penyedia Spare Part Otomotif Periode 2007-2011". Volume. 2, Nomor. 1, 2014. Yogyakarta: Universitas Sarjanawiyata Tamansiswa. 